\title{
Gender Disparities and the Role of Women in Smallholder Agriculture in Sub-Saharan Africa
}

\author{
Washington Muzari \\ Senior Lecturer, Department of Agricultural Engineering, Chinhoyi University of Technology
}

\begin{abstract}
Gender equality is a basic human right that requires that men and women be treated equally with respect to resources, legislation and policies. Gender-based discrimination results in serious gaps in political, social and economic participation. In subSaharan Africa, agriculture is the livelihood of nearly $70 \%$ of the economically active population. For the rural poor, agriculture is the main source of employment and income, although the income generated is low. A host of factors leading to low yields means that many households continue to be food insecure. High rates of hunger are strongly linked to gender inequality. The agricultural sector is underperforming in many sub-Saharan African countries, in part because women do not have equal access to the resources and opportunities they need to become more productive. Women smallholder farmers in the sub-Saharan African region face numerous constraints. They may have access to land but very few actually own or have title to it; their plots tend to be less fertile than those belonging to men; they have fewer farm tools and equipment; and limited access to farm credit, inputs, technologies and information. In addition, women farmers lack access to improved seeds, reliable water supplies, markets, financing and insurance options, and moreover, suffer from unsupportive public policies. Furthermore, smallholder African women farmers often do not get paid for the farm work that they do, nor do they always earn and control the income from sales, a factor that may affect their incentives to effectively participate in agricultural production. Research also shows that development policies and practices often exacerbate the situation as they do not offer women farmers equal access to development resources, training and information, thereby limiting their opportunities and ability to contribute to agricultural development, food security and poverty reduction. The household and societal pay-offs to reducing women's constraints in productive activities are significant. Closing the agricultural gender gap would result in significant gains for the agricultural sector as well as society as a whole. Increasing the opportunities for women can have a powerful impact on productivity and agricultural-led growth. Women are just as efficient agricultural producers as men and can achieve similar yields when given access to resources, including training and services.
\end{abstract}

Keywords: gender, employment, income, credit, inputs, technology, markets

\section{Introduction}

People often refer to the "triple roles" of gender: production, reproduction and community management (Tiruneh et al., 2001). The productive role involves the production of goods and services for consumption and trade. Work related to crop and livestock production (agricultural production) and other income-generating activities is regarded as productive. Reproductive work involves the care and maintenance of the household and its members. Collecting fuelwood and water, caring for children, cooking and cleaning are all considered reproductive work. These activities do not directly bring cash into the household and are often not even recognized as work. Community management work involves the collective organization of social events and services. Thus group work such as cleaning irrigation channels and terracing is viewed as community management.

In sub-Saharan Africa, both women and men play very significant roles in socio-economic activities at the family and community levels through smallholder agriculture. The exclusion of women in most agricultural development schemes is due to lack of access to land, technology, credit and many other challenges (Ngodoo \& Idisi, 2014). Gender equality is a basic human right that requires that men and women be treated equally with respect to resources, legislation and policies. Gender-based discrimination results in serious gaps in political, social and economic participation. The end result is a situation of persistent gender inequality (UN, 2013).

In sub-Saharan Africa, agriculture is the livelihood of nearly $70 \%$ of the economically active population (Tiruneh et al.,
2001). For the rural poor, agriculture is the main source of employment and income, although the income generated is low. A host of factors leading to low yields means that many households continue to be food insecure. High rates of hunger are strongly linked to gender inequality (AGRA, 2012). Indeed, according to the 2009 Global Hunger Index, countries with the most severe hunger problems also had high levels of inequality, and $90 \%$ of these countries are located in sub-Saharan Africa (AGRA, 2012). Historically, agriculture has been the engine for poverty reduction, food security and economic growth. Yet advances in food production are constrained by the ,invisibility factor ${ }^{\text {ee }}$ women's crucial but largely unrecognized roles in agriculture (AGRA, 2012). The agricultural sector is underperforming in many sub-Saharan African countries, in part because women do not have equal access to the resources and opportunities they need to become more productive (Ngodoo \& Idisi, 2014).

Overcoming stagnating agricultural production and food security in this sub-region hinges on increasing productivity in agriculture. In many parts of the sub-region where subsistence agriculture predominates, it is paramount to place strong emphasis on increasing the productivity of labour, land, capital and other resources (Ngodoo \& Idisi, 2014). There is a clear and urgent need to increase food production since a rapidly growing population and declining agricultural productivity risk leaving millions of people with inadequate and insecure sources of food (AGRA, 2012). Agricultural productivity may vary by gender if men and women use different technologies or different quantities of factors of production, or if there are differences in the quality of these (Saito et al., 1994). 


\section{International Journal of Science and Research (IJSR)}

ISSN (Online): 2319-7064

Index Copernicus Value (2013): 6.14 | Impact Factor (2014): 5.611

\section{Constraints faced by women smallholders in sub-Saharan Africa}

Women smallholder farmers in the sub-Saharan African region face numerous constraints. They may have access to land but very few actually own or have title to it; their plots tend to be less fertile than those belonging to men; they have fewer farm tools and equipment; and limited access to farm credit, inputs, technologies and information (Sibanda, 2012). In addition, women farmers lack access to improved seeds, reliable water supplies, markets, financing and insurance options, and moreover, suffer from unsupportive public policies.

Furthermore, smallholder African women farmers often do not get paid for the farm work that they do, nor do they always earn and control the income from sales, a factor that may affect their incentives to effectively participate in agricultural production. Research also shows that development policies and practices often exacerbate the situation as they do not offer women farmers equal access to development resources, training and information, thereby limiting their opportunities and ability to contribute to agricultural development, food security and poverty reduction (AGRA, 2012).

Women tend to be ,invisible ${ }^{\text {ee }}$ to policy makers because they are not often seen as ,productive ${ }^{\text {ee }}$ farmers in much of subSaharan Africa (Action Aid, 2011). In addition, women in the sub-region are often expected to provide unpaid farm work, and a disproportionate burden of care and reproductive roles within the family and the community. Women are deprived of access to markets, key assets and inputs, and are frequently excluded from decision making. Women are also disproportionately impacted by poverty and hunger, including having less access to education and health care services (Action Aid, 2011).

Poor farmers, who tend to be overwhelmingly women, are increasingly suffering from the impacts of climate change (Action Aid, 2011). Women farmers are particularly vulnerable to climate and environmental change effects, but few policies exist to address the potential impacts (AGRA, 2012).

Donors and international development agencies have taken a renewed interest in both agriculture and smallholders recently, especially in sub-Saharan Africa, but women farmers continue to be systematically neglected by agricultural policies. Even though some governments are promoting women farmers through specific gender policies, such moves have remain too rare (Action Aid, 2011). Often there are no specific budget lines allocated to women within the annual agricultural budget.

Statistics on women's yields, technology adoption rates and women's use of inputs are rarely reported. Increasingly the share of agricultural assistance that supports women farmers will require the use of tools such as gender budgeting and the collection and monitoring of sex-disaggregated data (Action Aid, 2011).
Women's constraints in accessing and using productive resources results in lower farm output. These constraints reflect underlying structural gender inequalities in subSaharan African rural societies, whose differential impacts are often shaped in many ways by clan, age, ethnicity and religion. Women in some countries have lower yields than men due to the inferior quality of their land, and women in other countries experience lower yields for the same crops due to diseconomies of scale caused by the smaller size of women"s plots compared with men"s (AGRA, 2012).

\section{The Case for Women in Smallholder Agriculture in sub-Saharan Africa}

The household and societal pay-offs to reducing women's constraints in productive activities are significant. Closing the agricultural gender gap would result in significant gains for the agricultural sector as well as society as a whole (World Bank, 2012; FAO, 2011). Increasing the opportunities for women can have a powerful impact on productivity and agricultural-led growth. Women are just as efficient agricultural producers as men and can achieve similar yields when given access to resources, including training and services. In some countries, women have even been found to be more efficient producers than men. In such countries, empirical evidence suggests that when women are provided with the same technologies and inputs as men, productivity on women "s farms is generally higher than on men's farms, and they tend to be more innovative farmers than men (AGRA, 2012).

When women's productivity and incomes increase, the benefits amplify across families and generations. Women tend to devote a larger traction of their income to their children 's health and nutrition, laying the foundation for their children's lifelong cognitive, psycho-motor and physical development. An increase in resources, particularly income, controlled by women is associated with intragenerational health, nutrition and education benefits. With similar access to resources as men, farm yields overall would increase substantially (AGRA, 2012).

Ensuring that women farmers get the same access to land and productive resources as men could reduce the number of hungry people in the world by $12-17 \%$, the majority of them in sub-Saharan Africa (FAO, 2011). Securing poor women farmers ${ }^{\text {ee }}$ access to and control over land is essential for basic livelihoods and household food security. Greater economic independence of women can also serve as a means out of poverty. Government measures such as securing land tenure, investing in water-harvesting structures, training in ecological farming practices, and more financial and market support, would help make ecologically sustainable farming methods more widespread among women smallholders. That would in turn improve living conditions, preserve the environment, and strengthen resilience to climate change (Action Aid, 2011)

Women are responsible for the food security of their households in many cultures and communities in subSaharan Africa. They have kitchen gardens and produce food crops for domestic consumption and often, they are the ones who travel to fetch water. Devising strategies and 


\section{International Journal of Science and Research (IJSR) \\ ISSN (Online): 2319-7064 \\ Index Copernicus Value (2013): 6.14 | Impact Factor (2014): 5.611}

providing support to improve women's control over productive resources and to better manage them will help enhance household food security.

Women are critical players in small farm production in subSaharan Africa. They are involved in all aspects of farming from sowing and planting to post-harvest processing and marketing, although to varying degrees in different locations. Recent empirical assessments in smallholder agriculture have shown that providing women farmers the same access to productive resources as men could increase yields on their farms by $20-30 \%$ (AGRA, 2012). This in turn could raise total agricultural output by $2.5-4.0 \%$ and thus significantly reducing the number of hungry people by 12 $17 \%$, the majority of them in sub-Saharan Africa. This would also transform the lives and economic livelihoods of millions of Africans, especially women and children, who would otherwise be hungry and suffer from high levels of malnutrition (AGRA, 2012).

\section{Gender disparities in access to resources}

\section{Land}

In spite of women's integral role in agriculture, women operate on an unlevel playing field. Women are five times less likely than men to own land. When women do own land, it often tends to be small, of inferior quality and typically with less secure tenure. Lack of secure tenure affects long term investment and thereby productivity and sustainability (AGRA, 2012).

Land tenure systems in sub-Saharan Africa vary across the sub-region. Both women's and men's access to land and security of women"s land tenure affects overall productivity (Ngodoo \& Idisi, 2014). Traditionally, land may be allocated through lineage or village heads, and this model persists despite increasing private or state ownership of land. In patrilineal societies women have access to land through male relatives. When land allocations are made by village heads, a lot depends on their perception of different individuals"e need for land. To the extent that women are perceived to be less capable of farming than men, their allocations are smaller (Doss, 1999). More often than not, women own smaller and less fertile landholdings than men in sub-Saharan Africa (FAO, 1995). Indeed, most women do not own the land which they farm. Customary practices and to a lesser extent legal provisions limit women's access to land and other productive resources (Action Aid, 2011).

Most customary law is unwritten, but emerges from social rules that ostensibly are derived from shared community values and traditions but which often reflect patriarchal relations between women and men. Under most systems of customary law, women (regardless of their marital status) cannot own or inherit land, property or housing in their own names, and whatever property rights they may enjoy are dependent upon their male relatives (COHRE, 2003). Women own only $1 \%$ of the land in sub-Saharan Africa (Action Aid, 2011).

Although the constitutions of many sub-Saharan African countries give equal property rights to women and men, tradition and womenes low social and economic status limit their ownership of assets. Overall, women 's access to land in African societies is quite restricted, even in cases where the law (constitution) protects women's rights to land, traditional customs inhibit their access and control over land (NPC, 2013).

Where smallholder farmers do get development support, a huge gender gap exists in terms of what women receive in relation to men. Women smallholder farmers often have less access than men to productive resources and government support, even though they make up the majority of smallholders (Action Aid, 2011).

\section{Crop Production and Animal Husbandry}

In the rural areas of sub-Saharan Africa, women make up the majority of smallholders producing $80 \%$ of food crops for home consumption (Foster, 1986). This distinction can be explained as a result of gender norms that assign women with the responsibility of feeding the family and men with the responsibility of providing cash income (Pitcher, 1996). In sub-Saharan Africa, female headed households have smaller farms and use fewer purchased inputs, and their output is as a result much smaller than that of male-headed households. Because of the limited access to productive resources, such as land, labour and inputs, the role of women in crop agriculture is often restricted to producing subsistence food crops with low potential to generate income (World Bank, 2010).

Net incomes from livestock are significantly higher in maleheaded households than in female headed households. In general, men are responsible for keeping and marketing large animals such as cattle, while women tend to control smaller animals such as goats, sheep, pigs, and poultry (FAO, 2009).

\section{Markets}

In many sub-Saharan African countries, culture determines if women can access markets to dispose of their agricultural products. Men often access larger markets than their female counterparts. Usually the output produced by women is small and it is consumed by the immediate family and sold at local community markets (Ngodoo \& Idisi, 2014). But even at local markets, women smallholder farmers have less access to sell their produce due to time constraints, little access to market information or lack of transport and facilities to add value to their produce.

\section{Credit}

Commercial banks are generally unwilling to grant loans to smallholder farmers. Among the major reasons is lack of collateral among smallholders. The banks also charge very high interest rates, thereby discouraging both female and male smallholders from borrowing (Action Aid, 2011; Ngodoo \& Idisi, 2014). Women in sub-Saharan Africa receive only $1 \%$ of all agricultural credit (Sanchez, 2005). Women farmerse adoption of agricultural technologies is often limited by lack of access to credit to purchase the required inputs (AGRA, 2012).

\section{Extension services}

Rural extension is the major institutional platform for farmers to access agricultural innovations and training to 


\section{International Journal of Science and Research (IJSR) \\ ISSN (Online): 2319-7064 \\ Index Copernicus Value (2013): 6.14 | Impact Factor (2014): 5.611}

increase agricultural productivity. Targeting women farmers in the provision of extension services is important because women smallholders provide most of the agricultural labour and are the dominant players in food production (AGRA, 2012).

Evidence demonstrates however that the development and dissemination of agricultural innovations rarely take genderspecific characteristics and requirements into consideration. For example, little is invested in the dissemination in the dissemination of innovations in post-harvest activities including food processing, which is predominantly undertaken by women farmers (AGRA, 2012).

Agricultural extension services can have a significant impact on productivity and output. Yet, extension provision in subSaharan Africa remains low for both men and women, and women tend to make less use than men of extension services (Meinzen-Dick et al., 2010). There is evidence that women are not adequately reached by extension services (Saito \& Weidemann, 1990). Extension services provide advice and training to enable farmers to use new inputs and methods to farm more productively, but women farmers have less access to these services, which tend to be tailored for men and commercial crops rather than to staple foods principally grown by women (Action Aid, 2011). Women receive only $7 \%$ of extension services in sub-Saharan Africa (Sanchez, 2005).

\section{Seeds and farming inputs}

Women smallholder farmers often do not have access to seeds and farming inputs (Action Aid, 2011). Appropriate farming inputs, including seeds, livestock breeds, farm tools and equipment, and fertilizers and manure, enable women farmers to farm sustainably, be more productive, and achieve food security. Because of restricted access, women are less likely to purchase and use inputs such as seeds and fertilizers (AGRA, 2012).

\section{Irrigation and drinking water}

Women farmers do not have secure access to and control over irrigation and drinking water in the sub-Saharan African region. Global warming and climate change pose an even greater threat to farming land and water supplies all over the world, with serious repercussions to the drier areas of sub-Saharan Africa (Action Aid, 2011). Access to clean and stable sources of water is essential for sustainable farming and food security.

\section{Research and technology}

Research and technology often bypass women smallholder farmers. For example, women farmers tend to use traditional hand-held hoes, because ploughs and irrigation equipment are often too heavy or otherwise inappropriate for women (Action Aid, 2011). Women have less access to and are less likely to use advanced technologies (AGRA, 2012).

Empirical research has linked the relevance of agricultural innovations to the diversity of actors in research. Yet African women scientists and development practitioners do not have a significant presence in technology generation or in the setting of research priorities as well as in technology transfer (AGRA, 2012). These gender disparities at the professional level tend to trickle down or translate into the generation and transfer of technology that is of little relevance to women smallholder farmers in the sub-region.

\section{Recommendations}

The multiple constraints faced by women mean that agricultural policies targeting women need to be different from those that have historically targeted men in smallholder farming systems of sub-Saharan Africa. Policy makers must start recognizing women farmers and their multiple roles, and ensure that well-funded and well-managed programmes specifically target women farmers. Appropriate extension services and training must also address the specific constraints women smallholders face. There is clearly a critical need to focus on actions to strengthen the capacity of the extension staff to understand how gender relations influence decision making processes and access to resources and markets. Strengthening women "s participation in farmer organizations is a critically strategic step in enabling women smallholder farmers ${ }^{e e}$ access to extension services.

Access to financial services including social transfers in the case of marginalized farmers, and credit for smallholder women farmers is essential so that they can pay for inputs, improve farming and small business enterprises, and empower them economically. To be sustainable, access to finance needs to accompany, or even follow, the resolution of more fundamental constraints that affect production, processing and marketing.

Appropriate research and technology are essential to develop new equipment, farming techniques and crops and livestock that are climate resilient, nutritious and high yielding. Appropriate marketing facilities including access to local markets and reliable information about markets and fair pricing are essential for economic empowerment.

Studies have shown that investing in women farmers increases overall crop production. But this potential will only be realized if rural women have better and fairer access to markets to sell their products.

Finally, building the capacities of women agricultural professionals, women leaders in farmer organizations and producer networks as well as female parliamentarians to effectively engage the policy making and planning process is a crucial step in enhancing gender-responsive policies in Africa.

\section{References}

[1] Action Aid (2011). How supporting women "s rights and gender equality makes the difference. Farming as Equals Report, 2011.

[2] Action Aid (2011). Investing in Women Smallholder Farmers.

[3] AGRA (2012). Gender Strategy and Action Plan. Alliance for a Green Revolution in Africa.

[4] COHRE (2003). A place to live: Women ${ }^{\text {ee }}$ Inherince Rights in Africa. Geneva: COHRE.

[5] Doss, C.R. (1999). Twenty-five years of research on women's farmers in Africa: Lessons and implications

\section{Volume 5 Issue 1, January 2016}




\section{International Journal of Science and Research (IJSR) \\ ISSN (Online): 2319-7064}

Index Copernicus Value (2013): 6.14 | Impact Factor (2014): 5.611

for agricultural institutions. CIMMYT Economics Program Paper No. 99-02.

[6] FAO (1995). Women, Agriculture and Rural Development: A Synthesis Report of the Africa Region. Rome: FAO.

[7] FAO (2011). The state of food and agriculture 20102011: Women in agriculture: Closing the gender gap for development. Rome, FAO.

[8] Foster, A. (1986). A common future for women and men (and all living creations). A submission to the World Commission on Environment and Development. EDPRA Consulting Inc., Ottawa, Canada.

[9] Meinzen-Dick, R., Quisumbing, A., Berham, J., Biermayr-Jenzano, P., Wilde, V., Noordeloos, M., Ragasa, C., and Beintema, N. (2010). Endendering agricultural research. IFPRI Discussion Paper No. 973. Washington, D.C.: IFPRI.

[10] Ngodoo, A.C. and Idisi, P.O. (2014). Inequality Gaps: Issues for Smallholder Farming in Nigeria. International Journal of Humanities and Social Science, Vol. 4 No. 11(1), September 2014.

[11] NPC (2013). Gender in Nigeria. Data from the National Demographic and Health Survey (NDHS) Report. National Population Commission.

[12] Pitcher, M. (1996). Conflicts and cooperation: gendered roles and responsibilities within the cotton households in Northern Mozambique. African Studies Review, Vol. 39 No.3

[13] Saito, K.A. and Weidemann, C.J. (1990). Agricultural Extension for Women Farmers in Africa. Washington, D.C.: World Bank.

[14] Saito, K.A., Mekonnen, H. and Spurling, D. (1994). Raising the productivity of women farmers in subSaharan Africa. World Bank Discussion Paper 230. Washington, D.C.: World Bank.

[15] Sanchez, P. (2005). Halving hunger: it can be done. New York: UNDP.

[16] Sibanda, L.M. (2012). Women in African Agriculture: farmers, mothers, innovators and educators. The Montpeller Panel.

[17] Tiruneh, A., Tesfaye, T., Mwangi, W. and Verkuijl, H. (2001). Gender differentials in agricultural production and decision-making among smallholders in Ada, Lume and Gimbichu Woredas of the Central Highlands of Ethiopia. CIMMYT.

[18]UN (2013). Gender Equality Briefing Kit. The United Nations Theme Group, Nigeria.

[19] World Bank (2012). World Development Report, 2012: Gender Equality and Development. Washington, D.C.: World Bank. 